\title{
Mortality of Cattle on Two Types of Grazing Areas in Northwestern Alberta
}

\author{
RONALD R. BJORGE
}

\section{Abstract}

Cattle mortality was investigated on 3 intensively managed Provincial Grazing Reserves (PGR) and 7 heavily treed, less intensively managed woodland grazing leases (Simonette pastures) in northwestern Alberta during 1976-1979 inclusive. Cattle losses (including dead and missing animals) on the Simonette pastures averaged 2.7 times greater than losses on the PGR. Calves were lost at a greater rate than yearlings and mature cattle on both types of grazing areas. Calves born on the Simonette pastures died at a rate nearly 5 times that of calves born prior to entering these pastures. Death from predation accounted for $48.4 \%$ of 33 recorded deaths on the Simonette pastures compared to $3.3 \%$ of 90 deaths on PGR. Greater losses of cattle on the Simonette pastures appeared associated with greater concentration of trees, less intensive supervision, and greater numbers and species of predators.

Unimproved native woodland pastures are commonly utilized for grazing cattle, particularly within the forest-farmland fringe areas of the western Canadian provinces. Although carrying capacity on unimproved woodland pastures is lower than on improved pastures (Wroe et al. 1979), little else is documented about the relative value of these areas for grazing.

Mortality of cattle was documented on 2 different types of grazing areas in northwestern Albcrta including 7 adjacent unimproved woodland grazing leases (Simonette pastures) and 3 separate Provincial Grazing Reserves (PGR). Management of the PGR was relatively intensive including removal of trees, seeding of tame forages, fencing, and full time supervision; management on the Simonette pastures was relatively unintensive. Mortality of cattle on both grazing regimes was determined to (a) test the hypothesis that cattle losses were greater on the Simonette pastures (unimproved woodlands that were unintensively managed) than on the PGR pastures (improved pasture lands that were intensively managed) and (b) to establish baseline mortality rates for cattle on these grazing areas. This research was part of ongoing investigations of wolf-cattle relationships in Alberta (Bjorge 1980, Bjorge and Gunson 1982). Rate and types of mortality occurring on the 2 grazing areas are summarized, and reasons for the differences are discussed.

\section{Study Areas}

The 3 PGR were located $60-160 \mathrm{~km}$ northwest of the Simonette pastures (Fig. 1), which were all located adjacent to one another near the Simonette River. The climate of the above area is characterized by warm summers and cold winters. Mean temperature for July was $16.0^{\circ} \mathrm{C}$ and $-13.5^{\circ} \mathrm{C}$ for December; the frost free period is 60-85 days. Average annual precipitation was about $440 \mathrm{~mm}$ (Atmospheric Environment Services, Environment Canada). The entire area is relatively flat with grey-wooded soils (Odynsky 1968), but interrupted with numerous creeks and rivers. Elevation varies from $670-760 \mathrm{~m}$, and the common tree cover is trembling aspen (Populus tremuloides).

\footnotetext{
The a uthor is a habitat biologist, Alberta Fish and Wildlife Division, 1801 Provincial Building 10328-99 St. Grande Prairie, Alberta T8V 6J4.

Grazing reserves staff of Alberta Public Lands Division provided pertinent data for the Provincial Grazing Reserves. W. Johnson assisted with cattle counts and investigation of cattle kills on the Simonette pastures. J. Gunson reviewed drafts of this paper. and $R$. Hunter drafted the figure. Leasees with cattle on the Simonet te pastures are thanked for their assistance.
}

\section{Simonette Pastures}

The Simonette pastures were all fully or partially surrounded by Green Area (a multiple use area where no agriculture other than grazing is allowed, Alberta Energy and Natural Resources 1979). Two of these pastures bordered farmland (Yellow Area, Alberta Energy and Natural Resources 1979); the remaining were $5-30 \mathrm{~km}$ into the Green Area. Total area occupied by the 7 Simonette pastures was $152 \mathrm{~km}^{2}$ with individual leases ranging from 5-59 $\mathrm{km}^{2}$. Trees had recently been cleared from about 285 ha on 1 lease. On the other pastures only occasional meadows and river flat were treeless; no pasture was free of trees on more than $10 \%$ of the area. Wolves (Canis lupus), black bea rs (Ursus americanus), and coyotes (Canis latrans) were all common; grizzly bears (Ursus arctos) were present, but relatively scarce. The Simonette pastures were leased or permitted to cattlemen for 1-10 year terms by Alberta Energy and Natural Resources. The administrating agency established stocking rates (which varied from approximately 2.0-5.0 ha/AUM), inspected condition of the range as required, established on-off dates, and collected fees. Cattlemen checked their own cattle periodically. Cattle in 6 of 7 pastures were owned by 1 cattleman. Cattle were driven to and from the cattlemen's headquarters each spring and fall, a mean dista nce of $24 \mathrm{~km}$. Two of the Simonette pastures were completely fenced, while the others were partially fenced.

Although governmental control of bears was available following documented attacks, only 1 bear was taken by this control during the 1976-1979 grazing seasons. However bears were hunted during hunting season and perhaps illegally, although no data pertaining to size of the kill were available. No governmental control of wolves was conducted during 1976-1979, as wolf research was being conducted during this period. However wolves were shot occasionally by big game licencees, trapped occasionally by regis-

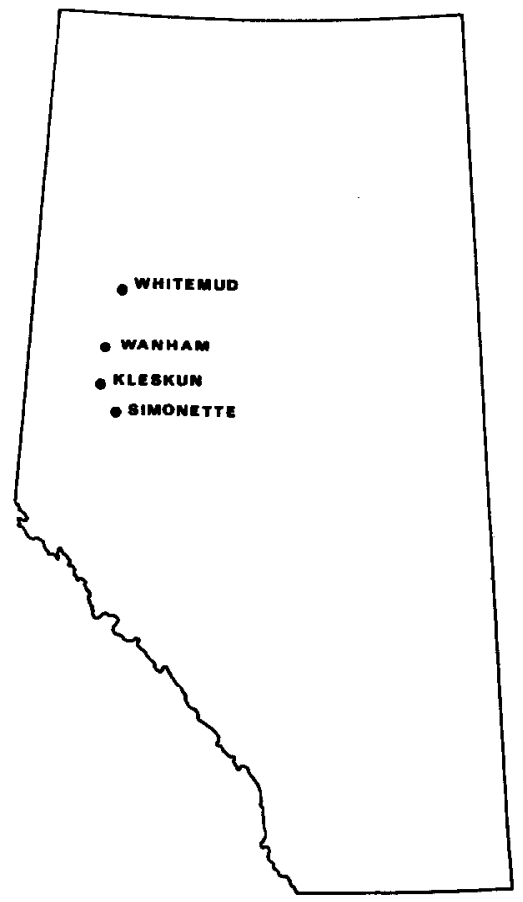

Fig. 1. Locations within Alberta of the Simonette pastures and 3 Provincial Grazing Reserves investigated in this study. 
tered trappers, and 6 wolves were illegally poisoned.

\section{Provincial Grazing Reserves}

One PGR (Kleskun Lake) was completely surrounded by farmland while the others (Whitemud and Wanham) bordered both farmland and Green Area. The PGR varied in size from approximately $39-75 \mathrm{~km}^{2}$. Sixty to $90 \%$ of the trees were removed from each PGR and the land was seeded to tame forage. Coyotes appeared common on all PGR, black bears on Wanham and Whitemud, and wolves on Whitemud.

PGR were administered by Alberta Public Lands Division. All cattle were inspected by veterinarians for signs of infectious disease prior to entering; sick animals were not admitted. A pasture manager and one or more riders managed the cattle, which belonged to approximately 40-60 patrons per PGR. Managers maintained records of cattle numbers entering and leaving leases and deaths which occurred. The Alberta government provided medicine for treatment of sick animals pastured on the PGR. Stocking rates were about .40 ha of improved pasture land/AUM, although pastures were not utilized to capacity during all years. All PGR were fenced and crossfenced. Bear and wolf control was available from Alberta Fish and Wildlife Division following confirmation of attacks. At least 7 wolves were removed from Whitemud between 1976 and 1979. No bears were removed by Fish and Wildlife Division on any of the PGR.

\section{Methods}

Data on mortality of cattle on PGR were obtained from records maintained by Alberta Public Lands Division of all cattle entering, leaving, and found dead. This information was recorded on standard forms by pasture managers. All cattle entering and leaving the Simonette pastures were counted and categorized by sex and age by the writer; dead cattle were examined and recorded by wolf study personnel and cattlemen. All cattle not located were presumed dead since there has never been evidence of cattle theft on the areas studied. Differences in mortality were tested for statistical significance by the $\mathrm{Chi}^{2}$ test.

\section{Results and Discussion}

Total cattle losses (including cattle dead and missing) averaged 2.7 times greater, during the 4-year study, on the Simonette pastures than the PGR (Table 1). Average loss for all cattle during the study was $3.3 \%$ on the Simonette pastures and $1.3 \%$ on the PGR $(P<0.005)$. Greater losses were evident for cows ( 2 years or older), calves (0-12 months), and yearlings (1-2 years) on the Simonette pastures versus PGR (all $P<.005$ ). Differences in mortality of bulls (2 years or older) were not significant.

Calves were lost at a greater rate than other cattle on both types of grazing areas (Table 1). Calf losses on the Simonette pastures were followed by those of yearlings, cows, and bulls, while those on PGR were followed by losses of bulls, yearlings, and cows. Greater mortality of calves over other classes appears common (Frisch 1973, Gee 1979).

Calves born on the Simonette pastures died at a rate nearly 5

Table 1. Losses of cattle on remote Simonette pastures and three Provincial Grazing Reserves (PGR) in northwestern Alberta during May through October grazing season, 1976-1979.'

\begin{tabular}{lccccc}
\hline \hline \multicolumn{2}{c}{ Provincial Grazing Reserves } & & \multicolumn{2}{c}{ Simonette Pastures } \\
\cline { 1 - 2 } \cline { 5 - 6 } Cattle class & $\begin{array}{c}\text { Cattle } \\
\text { entering }\end{array}$ & $\begin{array}{c}\text { Dead or } \\
\text { missing (\%) }\end{array}$ & & $\begin{array}{c}\text { Cattle } \\
\text { entered }\end{array}$ & $\begin{array}{c}\text { Dead or } \\
\text { missing (\%) }\end{array}$ \\
\hline Cows & 11197 & .61 & & 3135 & 1.33 \\
Calves & 10313 & 2.02 & & 2717 & 5.77 \\
Yearlings & 5067 & 1.06 & & 1691 & 3.31 \\
Bulls & 459 & 1.74 & & 110 & .90 \\
All classes & 27036 & 1.25 & & 7653 & 3.34 \\
\hline
\end{tabular}

ICattle were both PGR and Simonette pastures for 19 weeks except for 1976, when cattle were on the Simonette pastures for 21 weeks.
Table 2. Mortality factors of cattle dying of known causes on the Provincial Grazing Reserves and the Simonette pastures in northwestem Alberta.

\begin{tabular}{lcccc}
\hline \hline \multicolumn{2}{c}{ Provincial Grazing Reserves } & & \multicolumn{2}{c}{ Simonette Pastures } \\
\cline { 1 - 1 } \cline { 5 - 5 } Predation' & Other factors $^{2}$ & & Predation & Other factors \\
\hline $3(3.3)^{3}$ & $87(96.3)$ & & $16(48.4)$ & $17(51.6)$ \\
\hline
\end{tabular}

'Includes 2 deaths from black bears and 1 death from wolves on Provincial Grazing Reserves and 13 deaths from wolves and 3 from black bears on the Simonette pastures. ${ }^{2}$ Includes deaths from all causes other than predation.

${ }_{3}^{3}$ Percent of known mortality.

times greater $(P<0.005)$ than calves born prior to entering the leases. Of 143 cows which entered the Simonette pastures while visibily pregnant or were observed on these pastures with a calf, only $76.2 \%$ had calves when removed in fall ( $23.8 \%$ mortality). On the same pastures, of 2114 calves which entered in spring, mortality by time of removal in fall was $4.8 \%$. Few details of these mortalities are available; however, the death rate of calves born on the Simonette pastures (mean of $23.8 \%$ ) was much greater than that normally associated with birth. Frisch (1973) documented that $4.7 \%$ of the calves in that study died within 1 week of birth. In this study 3 newborn calves were documented to die of starvation because they were unable to suckle and one calf died at birth; however, no other records are available. Although the number of calves born on the Simonette leases was very small compared to those born before entering the leases, the significantly higher mortality of the former group is noteworthy. On PGR, patrons are not allowed to pasture pregnant cows.

Death from predation was much more common on the Simonette pastures than on the PGR (Table 2). Sixteen of 33 (48.4\%) deaths of known causes on the Simonette pastures were from predation compared to 3 of $90(3.3 \%)$ on the PGR. Wolves were documented to kill more cattle (13) than bears (3) on the Simonette pastures whereas 2 of 3 deaths from predators on the PGR was due to bears. Predation by coyotes was not documented.

Greater losses of cattle on the Simonette pastures over PGR appears related to 3 outstanding factors. These include much greater forest cover, less intensive management of the cattle and the range, and increased numbers and species of predators on the Simonette pastures compared to PGR. However other factors may also have contributed to differences in mortality. This study was not designed to determine precise reasons for differences in mortality between the 2 grazing areas.

Results of this study have implications for management. Agencies responsible for leasing unimproved woodland grazing areas such as the Simonette pastures should understand that mortality will likely be greater than on more intensively managed grazing areas. This message should be effectively relayed to livestock producers. Pregnant cows should not be placed on remote woodland pastures.

\section{Literature Cited}

Alberta Energy and Natural Resources. 1979. The administration and management of Alberta Public Lands. Alberta Energy and Natural Resources Rep. No. 85.

Bjorge, R.R. 1980. Management and research of the wolf-livestock conflict in Alberta. p. 71-76. In: Proceedings, Canadian Pest Management Society, Edmonton, Alta., 1980.

Bjorge, R.R., and J.R. Gunson 1982. Wolf predation of cattle on the Simonette River pastures in north west Alberta. In: L.N. Carbyn (Ed). Wolves, their status and management in Canada and Alaska. Canadian Wildl. Serv. Rep. (In press).

Frisch, J.E. 1973. Comparative mortality rates of Bos indicus and Bos taurus cattle in central Queensland. J. Exp. Agr. and Anim. Husb. 13:127-133.

Gee, C.K. 1979. Cattle and calf losses to predators-feeder cattle enterprises in the United States. J. Range Manage. 32:152-155.

Odynsky, W. 1968. Alberta soil survey report. Univ. Alberta. Edmonton. Wroe, R.A., S. Smoliak, A. Johnson, and M.G. Turnbull. 1979. Alberta range pastures. Alberta Energy and Natural Rep. No. 86. 